PREPARED FOR THE U.S. DEPARTMENT OF ENERGY, UNDER CONTRACT DE-AC02-76CH03073

PPPL-3700

PPPL-3700

UC-70

\title{
Operational Regimes \\ of the National Spherical Torus Experiment
}

by

D. Mueller, M.G. Bell, R.E. Bell, M. Bitter, T. Bigelow, P. Bonoli, M. Carter,

J. Ferron, E. Fredrickson, D. Gates, L. Grisham, J.C. Hosea, D. Johnson, R. Kaita, S.M. Kaye, H. Kugel, B.P. LeBlanc, R. Maingi, R. Majeski, R. Maqueda, J. Menard, M. Ono, F. Paoletti, S. Paul, C.K. Phillips, R. Pinsker, R. Raman, S.A. Sabbagh, C.H. Skinner, V.A. Soukhanovskii, D. Stutman, D. Swain, Y. Takase, J. Wilgen, J.R. Wilson, G.A. Wurden, and S. Zweben

June 2002
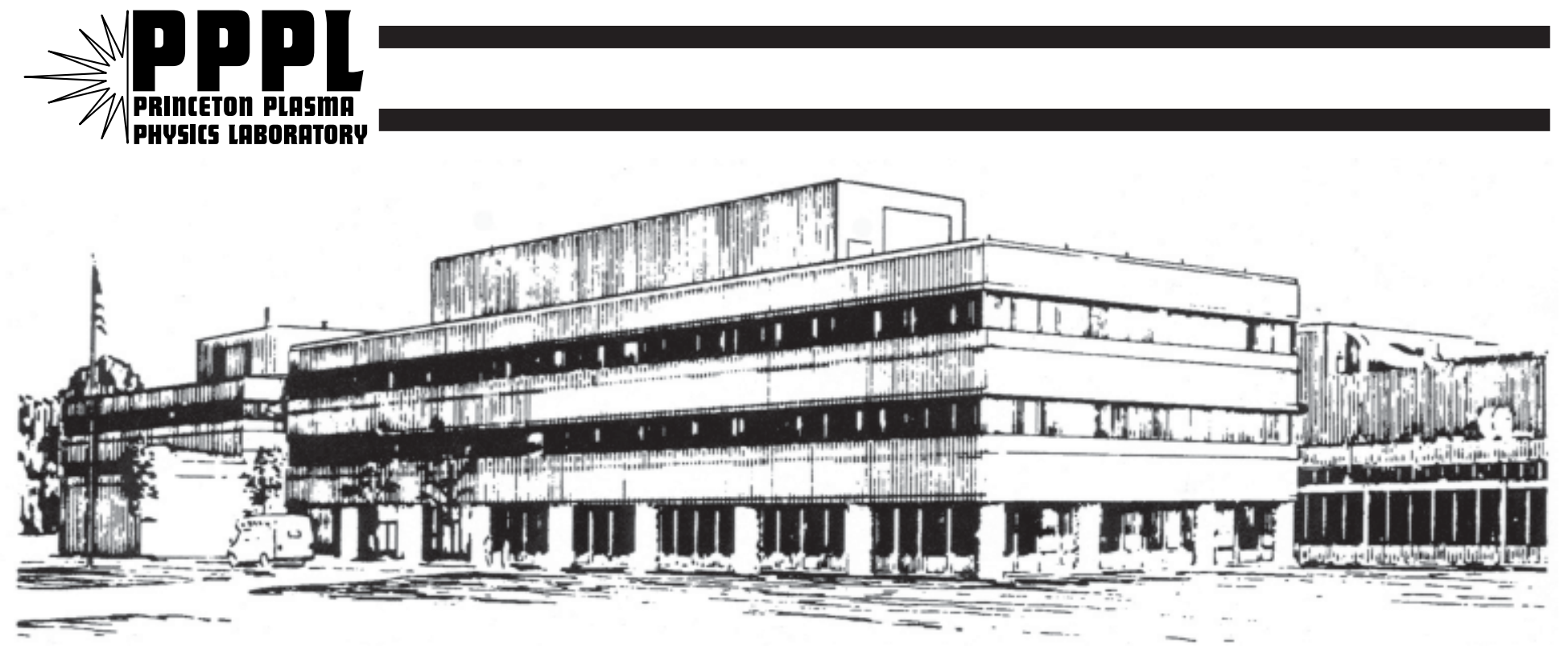

PRINCETON PLASMA PHYSICS LABORATORY PRINCETON UNIVERSITY, PRINCETON, NEW JERSEY 


\section{PPPL Reports Disclaimer}

This report was prepared as an account of work sponsored by an agency of the United States Government. Neither the United States Government nor any agency thereof, nor any of their employees, makes any warranty, express or implied, or assumes any legal liability or responsibility for the accuracy, completeness, or usefulness of any information, apparatus, product, or process disclosed, or represents that its use would not infringe privately owned rights. Reference herein to any specific commercial product, process, or service by trade name, trademark, manufacturer, or otherwise, does not necessarily constitute or imply its endorsement, recommendation, or favoring by the United States Government or any agency thereof. The views and opinions of authors expressed herein do not necessarily state or reflect those of the United States Government or any agency thereof.

\section{Availability}

This report is posted on the U.S. Department of Energy's Princeton Plasma Physics Laboratory Publications and Reports web site in Fiscal Year 2002. The home page for PPPL Reports and Publications is: http://www.pppl.gov/pub_report/

DOE and DOE Contractors can obtain copies of this report from:

U.S. Department of Energy

Office of Scientific and Technical Information

DOE Technical Information Services (DTIS)

P.O. Box 62

Oak Ridge, TN 37831

Telephone: (865) 576-8401

Fax: (865) 576-5728

Email: reports@adonis.osti.gov

This report is available to the general public from:

National Technical Information Service

U.S. Department of Commerce

5285 Port Royal Road

Springfield, VA 22161

Telephone: 1-800-553-6847 or

(703) 605-6000

Fax: (703) 321-8547

Internet: http://www.ntis.gov/ordering.htm 


\section{Operational Regimes of the National Spherical Torus Experiment*}

D. Mueller, ${ }^{1}$ M. G. Bell, ${ }^{1}$ R. E. Bell, ${ }^{1}$ M. Bitter, ${ }^{1}$ T. Bigelow,${ }^{3}$ P. Bonoli, ${ }^{2}$ M. Carter, ${ }^{3}$ J. Ferron, ${ }^{4}$ E. Fredrickson, ${ }^{1}$ D. Gates, ${ }^{1}$ L. Grisham, ${ }^{1}$ J.C. Hosea, ${ }^{1}$ D, Johnson, ${ }^{1}$ R. Kaita, ${ }^{1}$ S.M. Kaye,${ }^{1}$ H. Kugel, ${ }^{1}$ B.P. LeBlanc, ${ }^{1}$ R. Maingi, ${ }^{3}$ R. Majeski, ${ }^{1}$ R. Maqueda, ${ }^{5}$ J. Menard, ${ }^{1}$ M. Ono, ${ }^{1}$ F. Paoletti, ${ }^{6}$ S. Paul, ${ }^{1}$ C.K. Phillips,${ }^{1}$ R. Pinsker,${ }^{4}$ R. Raman, ${ }^{7}$ S.A. Sabbagh,${ }^{6}$ C.H. Skinner, ${ }^{1}$ V.A. Soukhanovskii, ${ }^{1}$ D. Stutman, ${ }^{8}$ D. Swain, ${ }^{3}$ Y. Takase, ${ }^{9}$ J. Wilgen, ${ }^{3}$ J.R. Wilson, ${ }^{1}$ G.A. Wurden, ${ }^{5}$ S. Zweben ${ }^{1}$

${ }^{1}$ Princeton Plasma Physics Laboratory, Princeton, New Jersey
${ }^{2}$ Massachusetts Institute of Technology, Cambridge, Massachusetts
${ }^{3}$ Oak Ridge National Laboratory, Oak Ridge, Tennessee
${ }^{4}$ General Atomics, San Diego, California
${ }^{5}$ Los Alamos National Laboratory, Los Alamos, New Mexico 87545
${ }^{6}$ Columbia University, New York, New York
${ }_{7}$ University of Washington, Seattle, Washington
${ }^{8}$ Johns Hopkins University, Baltimore, Maryland
${ }_{9}^{9}$ University of Tokyo, Tokyo, Japan

\section{Introduction}

The National Spherical Torus Experiment (NSTX) is a proof-of-principle experiment designed to study the physics of Spherical Torus (ST), i.e. low aspect-ratio toroidal, plasmas. Important issues for ST research are whether the high- $\beta$ stability and reduced transport theoretically predicted for this configuration can be realized experimentally. In NSTX, the commissioning of a digital real-time plasma control system, the provision of flexible heating systems and the application of wall conditioning techniques were instrumental in achieving routine operation with good confinement. NSTX has produced plasmas with R/a $\sim 0.85 \mathrm{~m} / 0.68 \mathrm{~m}, \mathrm{~A} \sim 1.25, \mathrm{I}_{\mathrm{p}} \leq 1.1 \mathrm{MA}, \mathrm{B}_{\mathrm{T}}=0.3-0.45 \mathrm{~T}, \kappa \leq 2.2, \delta \leq$ 0.5 , and with auxiliary heating by up to $4 \mathrm{MW}$ of High Harmonic Fast Waves, and $5 \mathrm{MW}$ of $80 \mathrm{keV} \mathrm{D}{ }^{0}$ Neutral Beam Injection (NBI). The energy confinement time in plasmas heated by NBI has exceeded $100 \mathrm{~ms}$ and a toroidal beta, $\beta_{\mathrm{T}}=2 \mu_{0}<\mathrm{p}>/ \mathrm{B}_{\mathrm{T} 0}^{2}$, where $\mathrm{B}_{\mathrm{T} 0}$ is the central vacuum toroidal magnetic field, up to $22 \%$ has been achieved. HHFW power of $2.3 \mathrm{MW}$ has increased the electron temperature from an initial $0.4 \mathrm{keV}$ to $0.9 \mathrm{keV}$ both with and without producing a significant density rise in the plasma. The early application of both NBI and HHFW heating has slowed the penetration of the inductively produced plasma current, modifying the current profile and, thereby, the observed MHD stability.

\section{Control System}

The Control system on NSTX is based on a Skybolt II 6U VME Multiprocessor system with $4 \mathrm{G} 4$ processors. The system uses measured coil currents and magnetics signals to calculate commands to control the power supplies. As currently implemented, this system can control the coil currents, plasma current, outer gap and the vertical position in closed feedback loops. The plasma elongation and triangularity are under open loop control by preprogramming the coil currents. The system will be upgraded later this year to provide 192 input channel capability at $100 \mathrm{kHz}$. The planned implementation will include 63 channels each of flux loop and B-field measurements as well as plasma 
current and coil current measurements. The results of offline EFIT ${ }^{1}$ analysis and RTEFIT ${ }^{2}$ simulations will be used to determine which flux loops, B-field measurements and measurements of structural currents are required to be included in the final real-time system. The system will be able to calculate the plasma shape using RTEFIT and update commands to the supplies in less than $1 \mathrm{~ms}$. This speed should be adequate for real-time NSTX shape control.

\section{Wall Conditioning}

The wall conditioning techniques include bakeout of internal components, glow discharge cleaning and boronization of the plasma facing components. The NSTX inner hardware is conditioned after vacuum vessel vents, prior to operation, by baking the graphite tiled center stack to $300^{\circ} \mathrm{C}$ and the outer vacuum vessel to $150^{\circ} \mathrm{C}$ by means of resistive heating of the vacuum vessel. $\mathrm{A}_{2}$ glow discharge (D-GDC) is used to remove complex hydrocarbons. Boronization using deuterated trimethylboron gas in a He glow discharge is effective in reducing the metallic and oxygen impurities found in subsequent high power discharges. ${ }^{3}$ This is followed by He glow discharge cleaning (He-GDC) to reduce the $\mathrm{D}_{2}$ in the plasma facing carbon components. Boronization is repeated as needed is found necessary to achieve good plasma performance. Between shot He-GDC
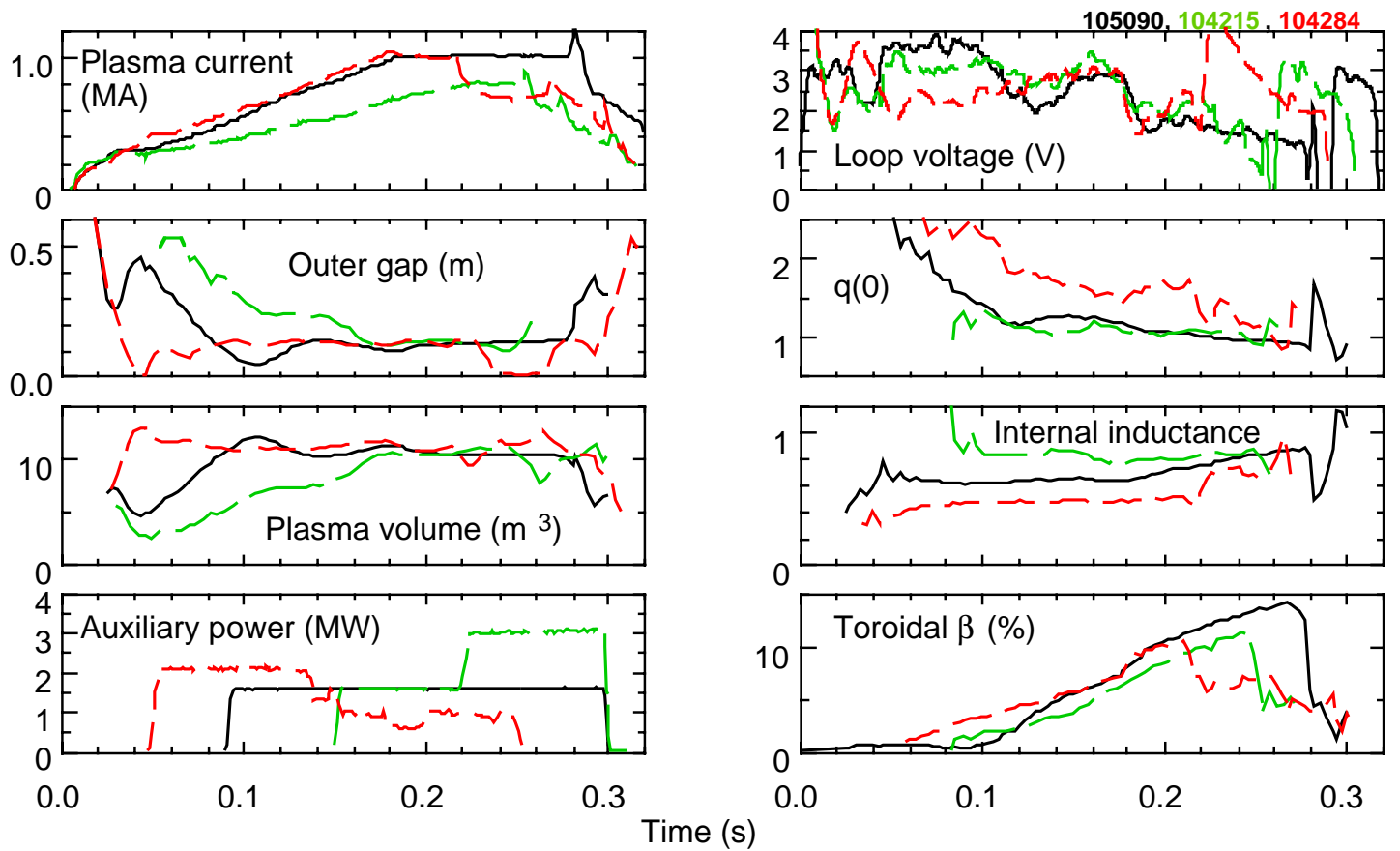

Figure 1. Evolution of plasma parameters for the three scenarios described in the

has been found necessary to provide reproducible response to wall conditions during routine operations. Between shot He-GDC provides more reproducible fueling during the breakdown and early ramp-up phases of the plasma (Ip < $200 \mathrm{kA}$ ) when open loop plasma control must be used due to the small size of the magnetic diagnostics signals. Varying wall conditions can result in plasma currents that range from 50 to $250 \mathrm{kA}$ at $20 \mathrm{~ms}$ with the same preprogrammed coil currents and fill pressure.

\section{Plasma Evolution}


The breakdown phase of plasmas on NSTX is now routinely achieved with $<3 \mathrm{~V} / \mathrm{turn}$. The poloidal field coils are used to produce a null in the poloidal field near the center stack at $3 \mathrm{~ms}$ while the ohmic transformer is ramped down to supply the breakdown voltage. Ten to thirty $\mathrm{kW}$ of Electron cyclotron power at $18 \mathrm{GHz}$ and hot filaments are used to assist ionization. After breakdown, the plasma current and position can be controlled to influence the profiles achieved later in the discharge. Figure 1 shows three different ramp-up scenarios. In the first, shown in green and heated with neutral beams, the plasma is begun as a small minor radius plasma limited on the center stack and is grown in size and current simultaneously so that $\mathrm{q}$ at the edge is approximately constant from $40 \mathrm{~ms}$ on. This results in a plasma that has $\mathrm{q}(0) \sim 1$ and a nearly constant internal inductance $\left(l_{\mathrm{i}}\right)$ of about 0.8 from EFIT analysis for plasma current above about $400 \mathrm{kA}$ and after $0.1 \mathrm{~s}$. In the second scenario, shown in red, the plasma is controlled so that it fills the available volume as soon as possible and has a nearly constant outer gap from 40 ms on while the plasma current is being increased to its final value. Such full-bore plasma ramps typically exhibit $\mathrm{q}(0)$ decreasing slowly from $\mathrm{q}(0) \sim 7$ at $40 \mathrm{~ms}$ to about 1.5 during the plasma current flattop until MHD activity or an impurity influx event causes $I_{p}$, $\mathrm{l}_{\mathrm{i}}$ and $\mathrm{q}(0)$ to undergo rapid changes. Use of High Harmonic Fast Wave (HHFW) heating during the early stage of this second scenario has been used to accentuate the desired effect of delaying the occurrence of $q(0)=1$. Most of the NSTX plasmas have been formed with an intermediate ramp-scenario like the neutral-beam-heated discharge shown in black in Figure 1. In this scenario, the final plasma position is achieved at about 100 ms or about $1 / 2$ the flattop plasma current value using a current ramp-rate of $\sim 5 \mathrm{MA} / \mathrm{s}$. Such plasmas typically have $\mathrm{q}(0)$ falling below 1 between 200 and 300 $\mathrm{ms}$ and have $l_{i}$ increasing from about 0.6 to 0.9 during the $I_{p}$ flattop.

NSTX plasmas can be heated with up to 3 energetic neutral beam sources at $80 \mathrm{keV}$ and up to $5 \mathrm{MW}$ total power and/or by (HHFW) at 30 $\mathrm{MHz}$ using an antenna array with 12 current straps aligned in the

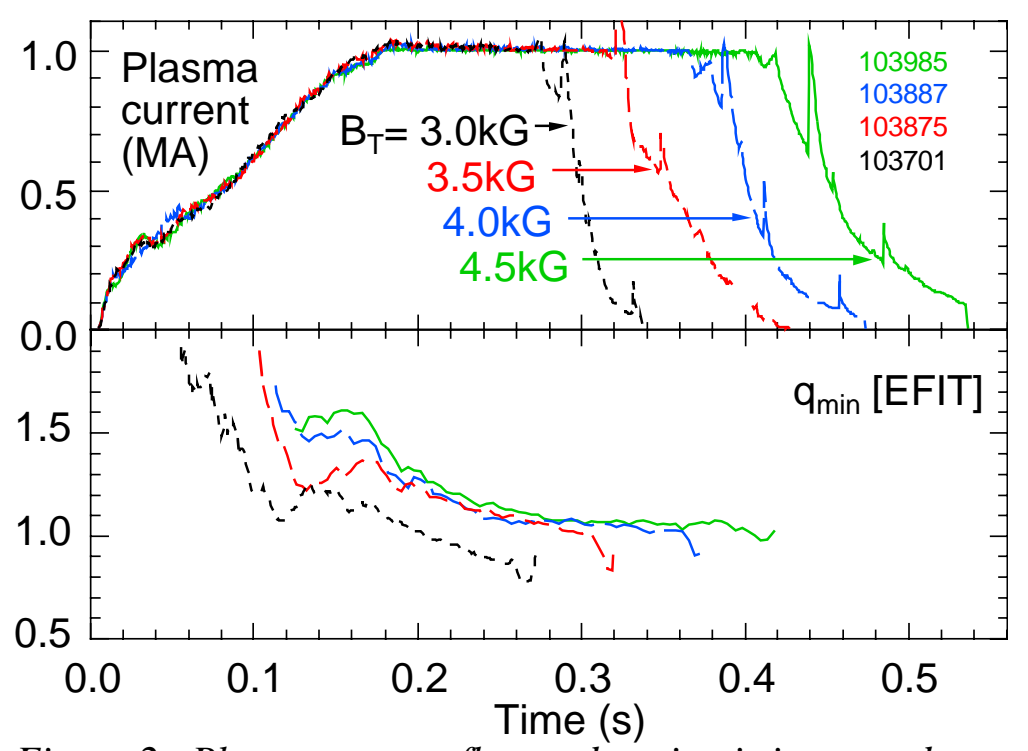

Figure 2. Plasma current flattop duration is increased when the toroidal field is raised. poloidal direction. ${ }^{4}{ }^{6}$ The presence of MHD activity can have significant impact on plasma performance during heating. In particular, when HHFW heating is applied after the onset of $\mathrm{m} / \mathrm{n}=1 / 1$ observed on the soft $\mathrm{x}$-ray array, plasma heating is observed, but the density increases very little and the density profile remains unchanged and 
asymmetrical. For comparison in the absence of $\mathrm{m} / \mathrm{n}=1 / 1$ activity, the plasma temperature and density both increase during HHFW and the density profiles are more symmetrical. During NBI heating, typically the current flattop is interrupted by an instability and only rarely does the flattop last until the ohmic transformer flux is exhausted. Often these events occur near a $\beta$ limit when $\beta_{\mathrm{N}}\left(\beta\right.$ a $\left.\mathrm{B}_{0} / \mathrm{I}_{\mathrm{p}}\right) \sim 3.5$ or $\beta_{\mathrm{pol}} \sim 0.4$ is reached. Figure 2 shows that raising the toroidal field $\left(\beta_{\phi}\right)$ increases the duration of the plasma current flattop. This increase is not due to an increase of $T_{e}$ with $\beta_{\phi}$, but rather MHD determines the pulse length. The reader is referred to papers by J. Menard ${ }^{7}$ and E. Fredrickson ${ }^{8}$ for more complete discussions of MHD on NSTX.

The current ramp-down phase on NSTX is generally filled with multiple instabilities that exhibit sharp changes in $\mathrm{I}_{\mathrm{p}}, \mathrm{l}_{\mathrm{i}}$, and $\mathrm{H}_{\alpha}$ and carbon light. Only a few, mainly lowcurrent, discharges have had the current ramped smoothly to near zero with no events. Attempts to bring the current down smoothly by puffing $\mathrm{D}_{2}$ gas during the ramp-down have so far had only a small degree of success.

The H-mode regime on NSTX has, so far, been observed only during neutral beamheated lower single null plasmas. ${ }^{9}$ It appears that access to the H-mode in NSTX is limited by wall conditions; discharges that are the same in terms of controlled parameters and in terms of most observed quantities can either transition to H-mode or not. The first H-modes on NSTX were observed after the third boronization and operation immediately following a boronization appears to make access to the H-mode easier to realize. The Hmode in NSTX is similar to the H-mode seen on tokamaks; the energy and particle confinement increase, $\mathrm{H}_{\alpha}$ and carbon light decrease and the electron density gradient is steeper than for L-mode.

\section{Summary}

The implementation of the digital control system and the use of the wall conditioning techniques and auxiliary heating methods have enabled the production of different operational scenarios on NSTX. These operational scenarios are essential ingredients in the production of plasma regimes with high confinement and high $\beta$. Local temperature, density and fluctuation measurements in these regimes will provide the data needed to test the understanding of the stability limits and plasma transport.

* Work supported at PPPL under U.S. DOE Contract DE-AC02-76CH03073

\section{References}

${ }^{1}$ L.L. Lao et al., Nucl. Fusion, 25, p. 1611 (1985).

${ }^{2}$ J. R. Ferron et al., Nucl. Fusion, 38, p. 1055, (1998).

${ }^{3}$ C.H. Skinner et al., submitted to Nucl. Fusion (2001).

${ }^{4}$ S. M. Kaye et al., Phys. Plasmas, 8, P. 1977, (2001).

${ }^{5}$ J.C. Hosea et al., This Conference

${ }_{7}^{6}$ B. P. LeBlanc et al., Proc. 14th Conf. RF Power in Plasmas (Oxnard 2001) Invited.

${ }^{7} \mathrm{~J}$. Menard, et al., this conference.

${ }^{8}$ E. Fredrickson, et al., this conference.

${ }^{9}$ R. Maingi et. al., submitted to Phys. Rev. Lett., 5/01 and this conference. 


\section{External Distribution}

Plasma Research Laboratory, Australian National University, Australia

Professor I.R. J ones, Flinders University, Australia

Professor J oão Canalle, Instituto de Fisica DEQ/IF - UERJ , Brazil

Mr. Gerson O. Ludwig, Instituto Nacional de Pesquisas, Brazil

Dr. P.H. Sakanaka, Instituto Fisica, Brazil

The Librarian, Culham Laboratory, England

Library, R61, Rutherford Appleton Laboratory, England

Mrs. S.A. Hutchinson, JET Library, England

Professor M.N. Bussac, Ecole Polytechnique, France

Librarian, Max-Planck-Institut für Plasmaphysik, Germany

J olan Moldvai, Reports Library, MTA KFKI-ATKI, Hungary

Dr. P. Kaw, Institute for Plasma Research, India

Ms. P.J . Pathak, Librarian, Insitute for Plasma Research, India

Ms. Clelia De Palo, Associazione EURATOM-ENEA, I taly

Dr. G. Grosso, Instituto di Fisica del Plasma, Italy

Librarian, Naka Fusion Research Establishment, J AERI, J apan

Library, Plasma Physics Laboratory, Kyoto University, J apan

Research Information Center, National Institute for Fusion Science, J apan

Dr. O. Mitarai, Kyushu Tokai University, J apan

Library, Academia Sinica, Institute of Plasma Physics, People's Republic of China

Shih-Tung Tsai, Institute of Physics, Chinese Academy of Sciences, People's Republic of China

Dr. S. Mirnov, TRINITI, Troitsk, Russian Federation, Russia

Dr. V.S. Strelkov, Kurchatov Institute, Russian Federation, Russia

Professor Peter Lukac, Katedra Fyziky Plazmy MFF UK, Mlynska dolina F-2, Komenskeho Univerzita, SK-842 15 Bratislava, Slovakia

Dr. G.S. Lee, Korea Basic Science Institute, South Korea

Mr. Dennis Bruggink, Fusion Library, University of Wisconsin, USA

Institute for Plasma Research, University of Maryland, USA

Librarian, Fusion Energy Division, Oak Ridge National Laboratory, USA

Librarian, Institute of Fusion Studies, University of Texas, USA

Librarian, Magnetic Fusion Program, Lawrence Livermore National Laboratory, USA

Library, General Atomics, USA

Plasma Physics Group, Fusion Energy Research Program, University of California at San Diego, USA

Plasma Physics Library, Columbia University, USA

Alkesh Punjabi, Center for Fusion Research and Training, Hampton University, USA

Dr. W.M. Stacey, Fusion Research Center, Georgia Institute of Technology, USA

Dr. J ohn Willis, U.S. Department of Energy, Office of Fusion Energy Sciences, USA

Mr. Paul H. Wright, Indianapolis, Indiana, USA 
The Princeton Plasma Physics Laboratory is operated by Princeton University under contract with the U.S. Department of Energy.

\author{
Information Services \\ Princeton Plasma Physics Laboratory \\ P.O. Box 451 \\ Princeton, NJ 08543
}

Phone: 609-243-2750

Fax: 609-243-2751

e-mail: pppl_info@pppl.gov

Internet Address: http://www.pppl.gov 